\title{
Implementation of a monitoring system in an automated fare collection system
}

\section{Budko Anna ${ }^{1}$}

Shapa Lyudmila ${ }^{2}$

Partyka Stanislav ${ }^{3}$
${ }^{1}$ Kharkiv National University of Radio Electronics, 14 Nauky Ave, KharkivUA-61166,Ukraine, anna.budko@nure.ua

${ }^{2}$ Kharkiv National University of Radio Electronics, 14 Nauky Ave, KharkivUA-61166, Ukraine, liudmyla.shapa@nure.ua

${ }^{3}$ Kharkiv National University of Radio Electronics, 14 Nauky Ave, KharkivUA-61166, Ukraine, stanislav.partyka@nure.ua

\begin{abstract}
This article describes the benefits of implementation of a monitoring system in an automated fare collection system and suggests some methods for its implementation.
\end{abstract}

Keywords: automated fare collection system, monitoring system, TMS, GSM.

\section{INTRODUCTION AND PROBLEM STATEMENT}

Nowadays, monitoring information systems are often used to obtain not only statistical information, but also for subsequent processing of this information. In particular, such systems are being actively implemented in public transport, because public transport monitoring can reduce costs of using public transport and if it is necessary reorganize public transport movement to improve service quality and road safety [2-4].

\section{PROBLEM SOLUTION AND RESULTS}

The implementation of a monitoring system in an automated fare collection system of public transport will allow:

1. Generate a history of movement for each vehicle and save this data to the archive.

2. To collect statistics on mileage, speed and perform the calculation of the average fuel consumption.

3. Organize control of which users and organizations can view information of monitoring system and carry out transactions.

4. Carry out messaging with drivers, control the situation on the road and predict delays.

5. Prohibit the misuse of public transport.

6. Inform about various target events.

7. Collect statistics on movements with subsequent transfer to the accounting system and analysis.

8. Control of working hours, including continuous driving of one driver.

9. Speed monitoring.

Also, additional functions will become possible due to sharing TMS modules with the monitoring system. For example, it will be possible to compare the actual movement of the public transport with the planned route or to inform about events such as deviation from the route, fuel drain, engine shutdown, etc.

To relieve the operator from the need to constantly monitor the status of transport in the online mode, in the TMS monitoring module can be implemented the ability to generate messages to the operator about different events on the road. But this requires the installation of additional sensors, on the basis of which information will be generated, such as accurate fuel gauges, opening or closing doors, temperature control etc.

Control over the actions of drivers will lead to a reduction in GSM costs by $10-15 \%$, which will cover the cost of GPS monitoring services.
The monitoring system can be implemented using a GPS module integrated in an automated fare collection system. This will expand the capabilities of AFC system, which in turn has everything necessary to receive, store and process the necessary information about the transaction. Then it can transfer all the necessary information to the processing center, where real-time information processing will be recorded.

According to the research work [1] bandwidth consumption with the available public transport mode for a month is not more than 50 megabytes, which is $9 \%$ of the total traffic for the transmitting GPS coordinates.

The obtained data can either be accumulated in a GPS tracker or in on-board computer and then transferred to a central base, or transmitted to a central server in real time mode to a processing center.

Nevertheless, it is necessary to comprehensively study the effectiveness of implementing public transport monitoring. It is also necessary to provide competently administrative management of the monitoring system and ensure the security of information in the monitoring system, because intruders can use it for their own purposes.

\section{CONCLUSIONS}

Thus, the implementation of a monitoring system in an automated fare collection system will provide many advantages that can improve public transport system to a new level of service.

Using monitoring systems allows to collect data from devices with one or more communication servers, Then it redirects databases to the main server and distribute them between connected intermediate servers that will provide user interaction or performing background tasks. Such a construction of the monitoring system will allow users from different regions to work with the closest regional web server with a minimum delay to it.

\section{REFERENCES}

[1] Yeromina N. S., Shapa L. S., Budko A. O. "Using of global positioning system navigation services in automated fare collection systems", CSITIC, pp. 51-52, April 2018.

[2] Guilin L. D., Zhang J. Z. Shaohua C. Vehicle Monitor System for Public Transport Management Based on Embedded Technology, Physics Procedia, vol. 24, pp. 953-960, March 2012.

[3] Martovitskii, V. A., Ruban, I. V. Model' mul'tiagentnoi sistemy sbora i khraneniya informatsii. Sistemi upravlinnya, navigatsiï ta zv'yazku, (6), 150-153.

[4] Martovytskyi V. O. Arkhitektura multyahentnoi systemy monitorynhu rozpodilenykh informatsiinykh system / V.O. Martovytskyi, K. R. Lokotetska // tezy dopovidei KhXVII mizhnarodnoi naukovopraktychnoi konferentsii MicroCAD-2019, 15-17 travnia 2019 r.: u 4 ch. Ch. IV «Informatsiini tekhnolohii: nauka, tekhnika, tekhnolohiia, osvita, zdorovia». - Kh. : NTU «KhPI», 2019. - S. 164. 